\title{
Syzygium jambos Displayed Antibacterial and Antibiotic-Modulating Activities against Resistant Phenotypes
}

\author{
Brice E. N. Wamba, Paul Nayim, Armelle T. Mbaveng (D), Igor K. Voukeng, \\ Joachim K. Dzotam, Ornella J. T. Ngalani, and Victor Kuete $\mathbb{C}$ \\ Department of Biochemistry, Faculty of Science, University of Dschang, Dschang, Cameroon \\ Correspondence should be addressed to Armelle T. Mbaveng; armbatsa@yahoo.fr and Victor Kuete; kuetevictor@yahoo.fr
}

Received 15 November 2017; Accepted 15 January 2018; Published 7 March 2018

Academic Editor: Letizia Angiolella

Copyright ( 2018 Brice E. N. Wamba et al. This is an open access article distributed under the Creative Commons Attribution License, which permits unrestricted use, distribution, and reproduction in any medium, provided the original work is properly cited.

\begin{abstract}
The present study was designed to evaluate the antibacterial activities of methanol extracts of bark and leaves of Syzygium jambos, as well as their synergistic effects with selected antibiotics against drug-resistant Gram-positive and Gram-negative bacteria. The crude extracts were subjected to qualitative phytochemical screening; broth microdilution method was used for antibacterial assays. Phytochemical studies indicate that leaves and bark extracts contained polyphenols, anthraquinones, tannins, and steroids. Extract of the leaves was active against all the 26 strains of Staphylococcus aureus and all the 21 strains of Gram-negative bacteria tested, within the minimum inhibitory concentration (MIC) range of $32-512 \mu \mathrm{g} / \mathrm{mL}$. The lowest MIC value of $32 \mu \mathrm{g} / \mathrm{mL}$ was obtained with extract of the leaves against Staphylococcus aureus MRSA9 strain. In Gram-negative bacteria, the lowest MIC value of $64 \mu \mathrm{g} / \mathrm{mL}$ was also obtained against Enterobacter aerogenes EA294 and Klebsiella pneumoniae K24 strains. Against S. aureus strains, antibioticmodulating activity of extracts at $\mathrm{MIC} / 2$ towards more than $70 \%$ of the tested strains was obtained when leaves and bark extracts were tested in association with chloramphenicol (CHL). This was also the case when leaves extract was combined with CHL, kanamycin (KAN), tetracycline (TET), and erythromycin (ERY) and when bark extract was combined with ciprofloxacin (CIP), TET, and ERY against Gram-negative bacteria. In conclusion, this study demonstrated that Syzygium jambos has antibacterial and antibiotic-modulating activities.
\end{abstract}

\section{Introduction}

Infectious diseases cause 15 million deaths every year, accounting for about $27.12 \%$ of deaths worldwide [1]. Multidrug-resistant (MDR) bacteria are responsible for therapeutic failures, leading to an increase disease burden [2]. Despite the various technological and medical-pharmaceutical advances, MDR bacteria still remain a major cause of morbidity and mortality globally. The search for new antibacterial substances should therefore take into account the development of resistance by pathogenic bacteria. With regard to the high diversity of secondary metabolites in plant kingdom, botanicals constitute a good reservoir for drug discovery to combat MDR bacteria [3,4]. Also, the loss of efficacy of several antibiotics and the scarcity of new antibacterial agents propel the search for substances capable of restoring the activity of antibiotics. African medicinal plants have previously shown efficiency against MDR bacteria with some of them being able to modulate the activity of antibiotics. Some of these plants include Xanthosoma mafaffa, Moringa oleifera, Passiflora edulis [5], Anthocleista schweinfurthii, Nauclea latifolia, Zehneria scabra [6], Nauclea pobeguinii [7], Catharanthus roseus, Croton macrostachys, Paullinia pinnata [8], Albizia adianthifolia, Alchornea laxiflora, Laportea ovalifolia [9], Mangifera indica [10], Ricinodendron heudelotii [11], and Euphorbia prostrata [12]. In our continuous search for new botanicals to combat MDR bacteria as well as potentiate the activity of antibiotics, we targeted another African plant, Syzygium jambos (L.) Alston. (Myrtaceae). This plant is used traditionally to treat abdominal pain, diarrhea, amenorrhea, pernicious attacks [13], epilepsy, asthma, bronchitis, diuretics, rheumatism, smallpox and eye 
irritation [14], respiratory disorders, eczema, malaria, and infectious diseases [15]. Previous studies have reported the antibacterial effects of extracts of bark, leaves, and seeds of Syzygium jambos against sensitive phenotypes [14]. The present study was aimed at evaluating the antibacterial effects of this plant against resistant phenotypes as well as its ability to reverse the antibiotic resistance. The antibioticmodulating effect of this plant is being reported for the first time.

\section{Material and Methods}

2.1. Plant Material and Extraction. The leaves and bark of Syzygium jambos (L.) Alston. (Myrtaceae) were collected in Dschang, Western Region of Cameroon, in April 2016. The plant was identified at the National Herbarium in Yaoundé (Cameroon) where the voucher specimen was conserved under the registration number $30458 / \mathrm{HNC}$. The dried and powdered material $(100 \mathrm{~g})$ was macerated in $300 \mathrm{~mL}$ of methanol at room temperature for $48 \mathrm{~h}$ and then filtered using Whatman filter paper number 1 . The filtrate obtained was concentrated using a rotary evaporator under reduced pressure to obtain the crude methanol extract, which was kept at $4^{\circ} \mathrm{C}$ until further use.

2.2. Chemicals. Eight reference antibiotics (RA) purchased from Sigma-Aldrich (St Quentin Fallavier, France) were tested: ampicillin (AMP), cefepime (CEF), chloramphenicol (CHL), ciprofloxacin (CIP), erythromycin (ERY), kanamycin (KAN), streptomycin (STR), and tetracycline (TET). p-Iodonitrotetrazolium chloride (INT) (Sigma-Aldrich) was used as bacterial growth revelator; dimethylsulfoxide (DMSO) was used to dissolve the plant extracts.

2.3. Bacteria, Culture Media, and Growth Conditions. The tested bacteria included various strains of a Gram-positive bacterium, Staphylococcus aureus, and a panel of Gramnegative bacteria. The strains of Staphylococcus aureus used were as follows: a reference strain obtained from American Type Culture Collection (ATCC) (ATCC 25923), 1 methicillin-sensitive $S$. aureus (MSSA1), 7 methicillin-resistant S. aureus (MRSA) strains (MRSA3, MRSA4, MRSA6, MRSA8, MRSA9, MRSA11, MRSA12) (obtained from the culture collection of the Laboratory of Microbiology, Graduate School of Pharmaceutical Sciences, The University of Tokyo, Japan, and provided by Dr. Dzoyem of the University of Dschang) [16, 17], and 17 resistant clinical laboratory strains of $S$. aureus (SA01, SA07, SA18, SA23, SA36, SA39, SA56, SA64, SA68, SA88, SA114, SA116, SA124, SA126, SA127, SA135, SA139) available in our Laboratory collection and previously isolated from patients in Ad-Lucem Hospital in Banka-Bafang (West Region of Cameroon) [18]. Gramnegative bacteria included MDR isolates (laboratory collection) and reference strains of Escherichia coli (ATCC8739, AG100, AG100ATet, AG102, MC4100), Enterobacter aerogenes (ATCC13048, CM64, EA3, EA27, EA289, EA298, EA294), Klebsiella pneumoniae (ATCC11296, KP55, KP63, K24), Enterobacter cloacae (ECCI69), Pseudomonas aeruginosa (PA01, PA124), and Providencia stuartii (NEA16, PS299645).
The clinical strains were the laboratory collection from UMR-MD1, University of Marseille, France. Their bacterial features are reported in Tables S1 and S2 (Supplementary Materials). The microorganisms were cultured overnight on Mueller Hinton Agar $24 \mathrm{~h}$ prior to any assay. The Mueller Hinton Broth (MHB) was used as liquid culture medium for susceptibility assays.

2.4. Preliminary Phytochemical Screenings. Potential classes of antibacterial secondary metabolites such as alkaloids (Dragendorff's and Mayer's tests); terpenoids: sterols (Salkowski's test), saponins (Foam test), and triterpenes (Liebermann-Burchard test); and phenolics: anthraquinones (Borntrager's test), flavonoids (Aluminum chloride test), polyphenols (Ferric chloride test), and tannins (Gelatin test) (Table 3) were investigated according to described phytochemical methods $[4,19]$.

2.5. INT Colorimetric Assay for MIC and Minimum Bactericidal Concentration (MBC) Determinations. The MIC and minimum bactericidal concentration (MBC) determinations on bacteria were performed using the rapid INT colorimetric assay [20] with some modifications as previously described [21]. Samples were dissolved in DMSO/MHB. The final concentration of DMSO was lower than $2.5 \%$. The twofold dilutions of samples were made in 96-well microplates and the tested bacterial concentration was $1.5 \times 10^{6}$ colony forming unit $(\mathrm{CFU}) / \mathrm{mL}$. The microplates were incubated at $37^{\circ} \mathrm{C}$ for $18 \mathrm{~h}$. All assays were in triplicate and repeated thrice. Wells containing $\mathrm{MHB}, 100 \mu \mathrm{L}$ of inoculum, and DMSO to a final concentration of $2.5 \%$ served as negative control. The MIC of each sample was detected after $18 \mathrm{~h}$ incubation at $37^{\circ} \mathrm{C}$, following addition $(40 \mu \mathrm{L})$ of $0.2 \mathrm{mg} / \mathrm{mL}$ of INT and incubation at $37^{\circ} \mathrm{C}$ for 30 minutes as the lowest sample concentration that prevented the color change of the medium and exhibited complete inhibition of microbial growth [20]. The $\mathrm{MBC}$ was determined by adding $50 \mu \mathrm{L}$ aliquots of the preparations, which did not show any growth after incubation during MIC assays, to $150 \mu \mathrm{L}$ of MHB. These preparations were further incubated at $37^{\circ} \mathrm{C}$ for $48 \mathrm{~h}$. The $\mathrm{MBC}$ was regarded as the lowest concentration of a sample, which did not induce a color change after addition of INT as mentioned above [21].

2.6. Antibiotic-Activity Modulation Assays. To evaluate the antibiotic-resistance modulating activity of extracts, a preliminary assay was performed to determine the MICs of antibiotics in the absence and presence of these extracts using broth microdilution method as previously described [20-22]. S. aureus SA88 and P. aeruginosa PA124 were used for preliminary assays and samples were tested at various subinhibitory concentrations (MIC/2, MIC/4, MIC/8, and $\mathrm{MIC} / 16)$. Results allowed selecting $\mathrm{MIC} / 2$ and $\mathrm{MIC} / 4$ as subinhibitory concentrations for further experiments on selected $S$. aureus strains as well as Gram-negative bacteria. Briefly, after serial dilution of antibiotic, extract was added to each well at its subinhibitory concentration and the bacterial inoculation was done; the MIC was further determined. Rows receiving antibiotic dilutions without extracts were used for 
TABLE 1: Extraction yields and phytochemical composition of the plant extracts of Syzygium jambos.

\begin{tabular}{lcc}
\hline Phytochemical classes & \multicolumn{2}{c}{$\begin{array}{c}\text { Plant parts, yield (\%), } \\
\text { and composition }\end{array}$} \\
& Bark & Leaves \\
\hline Yields (\%) & 8.2 & 21.2 \\
Alkaloids & - & - \\
Polyphenols & + & + \\
Flavonoids & - & - \\
Anthraquinones & + & + \\
Tannins & + & + \\
Triterpenes & + & - \\
Steroids & + & + \\
Saponins & + & - \\
\hline
\end{tabular}

$(-)$ : absent; $(+)$ : present; yield calculated as the ratio of the mass of the obtained methanol extract/mass of the plant powder.

the determination of the MICs of the antibiotics. The modulation factor was defined as the ratio of the MIC of antibiotic alone versus that of antibiotic in the presence of extract. Modulation factor $\geq 2$ was set as the cut-off for biologically significance of antibiotic-resistance modulating effects [23].

\section{Results}

3.1. Phytochemical Composition of Plant Extracts. The major classes of phytochemicals in the leaves and bark extracts from Syzygium jambos were assessed and the results are summarized in Table 1. Both leaves and bark extracts contained polyphenols, anthraquinones, tannins, and steroids whilst alkaloids and flavonoids were absent. Triterpenes and saponins were found only in the bark extract.

3.2. Antibacterial Activity. The antibacterial activity of leaves, bark extracts, and CIP against 26 strains of S. aureus (Table 2) or CHL against 21 Gram-negative bacteria (Table 3) was determined. Results showed that leaves extract was active against all the strains of $S$. aureus and Gram-negative bacteria within the MIC range of $32-512 \mu \mathrm{g} / \mathrm{mL}$. The bark extract had selective activity, with MIC values below or equal to $1024 \mu \mathrm{g} / \mathrm{mL}$ being obtained on 22/26 (84.6\%) strains of $S$. aureus (Table 2) and 10/21 (47.6\%) strains of Gram-negative bacteria (Table 3). The lowest MIC value of $32 \mu \mathrm{g} / \mathrm{mL}$ was noted with the leaves extract against $S$. aureus MRSA9 strain. In Gram-negative bacteria, the lowest MIC value of 64 $\mu \mathrm{g} / \mathrm{mL}$ was obtained against Enterobacter aerogenes EA294 and Klebsiella pneumoniae K24 strains. The MICs of RA were below $4 \mu \mathrm{g} / \mathrm{mL}$ for CIP against $S$. aureus strains and between 4 and $128 \mu \mathrm{g} / \mathrm{mL}$ for CHL against Gram-negative bacteria. MBC values in the range of $128-1024 \mu \mathrm{g} / \mathrm{mL}$ were recorded with leaves extract against all 26 tested $S$. aureus strains and against 17/21 (33.3\%) strains of Gram-negative bacteria. The $\mathrm{MBC} / \mathrm{MIC}$ ratios generally ranged from 2 to 8 for the leaves extract on tested bacteria. However, with bark extract, no recordable $\mathrm{MBC}$ value was noted against $S$. aureus strains whilst it was detected against two Gram-negative bacteria (Table 3).

3.3. Antibiotic-Resistance Modulation Activity of Extracts. Leaves and bark extracts at $\mathrm{MIC} / 2, \mathrm{MIC} / 4, \mathrm{MIC} / 8$, and MIC/16 were first tested in combination with 8 antibiotics: CHL, TET, CIP, AMP, CEF, ERY, STR, and KAN against S. aureus SA88 and P. aeruginosa PA124 strains (Table 4). It appears that the best antibiotic-modulation effects were obtained with the two extracts at MIC/2 and MIC/4. In effect, at MIC/2 and MIC/4 of leaves extract, 2 -fold or more increases in antibiotic activities were obtained with $5 / 8$ and $6 / 8$ tested antibiotics, respectively, against $S$. aureus SA88 and with $6 / 8$ and $7 / 8$ tested antibiotics, respectively, against $P$. aeruginosa PA124. Better increases in antibiotic activities were also obtained with bark extract at MIC/2 and MIC/4. Consequently, the two extracts were further tested in combination with the above antibiotics against the reference strains (ATCC 25923), 8 resistant strains of S. aureus, and 10 Gram-negative bacteria, at MIC/2 and MIC/4 (Tables 5-8). Results showed that 2 -fold or more increases of the activity of antibiotics against more than $70 \%$ tested strains of S. aureus were obtained when leaves and bark extracts were combined with CHL at MIC/2 (77.78\% and $88.89 \%$, resp.) (Tables 5 and 6). Corresponding results against Gram-negative bacteria were also obtained when leaves extract was combined with CHL $(90 \%$ and $80 \%$ at $\mathrm{MIC} / 2$ and $\mathrm{MIC} / 4$, resp.), KAN at $\mathrm{MIC} / 2$ (80\%), TET (80\% at MIC/2 and MIC/4), and ERY at MIC/2 (80\%) (Table 7). This was also the case when bark extract was combined with CIP and TET at MIC/2 (70\%) and with ERY ( $80 \%$ and 70 at $\mathrm{MIC} / 2$ and $\mathrm{MIC} / 4$, resp.) (Table 8).

\section{Discussion}

4.1. Phytochemical Composition of Extracts. Polyphenols, anthraquinones, tannins, and steroids were detected leaves and bark extracts (Table 1). The role of several molecules belonging to polyphenols as antibacterials has been demonstrated $[3,4,24]$. Tannins and anthraquinones also belong to a class of polyphenols and their presence in the two extracts could in part explain their antibacterial effects [3]. Previous phytochemical studies of the bark of this plant led to the isolation of triterpenoids such friedelin, $\beta$-amyrin acetate, betulinic acid, and lupeol from the bark of the plant [25]. This consolidates the presence of triterpenoids in the investigated bark extract.

4.2. Antibacterial Potential of Extracts. Overcoming the bacterial resistance to antibiotics is a major challenge in the treatment of infectious diseases. The scarcity of new antibacterials to fight resistant pathogens propels the search for new agents from natural sources. The activity of newly discovered chemotherapeutic agents should take into account the ability of bacteria to rapidly develop resistant phenotypes. In this study, clinical strains of $S$. aureus as well as several Gramnegative bacteria tested were previously reported as resistant 
TABLE 2: MIC and MBC (in $\mu \mathrm{g} / \mathrm{mL}$ ) of extracts from Syzygium jambos and ciprofloxacin against Staphylococcus aureus strains.

\begin{tabular}{|c|c|c|c|c|c|c|c|c|c|}
\hline \multirow{3}{*}{ Staphylococcus aureus strains } & \multicolumn{9}{|c|}{ Tested sample, MIC, and $\mathrm{MBC}$ in $\mu \mathrm{g} / \mathrm{mL}$ and ratio $\mathrm{MBC} / \mathrm{MIC}$} \\
\hline & \multicolumn{3}{|c|}{ Leaves extract } & \multicolumn{3}{|c|}{ Bark extract } & \multicolumn{3}{|c|}{ Ciprofloxacin } \\
\hline & MIC & $\mathrm{MBC}$ & $\mathrm{MBC} / \mathrm{MIC}$ & MIC & $\mathrm{MBC}$ & $\mathrm{MBC} / \mathrm{MIC}$ & MIC & $\mathrm{MBC}$ & $\mathrm{MBC} / \mathrm{MIC}$ \\
\hline ATCC25923 & 64 & 512 & 8 & 1024 & - & - & $<0.5$ & 16 & $<32$ \\
\hline SA01 & 256 & 512 & 2 & - & - & - & $<0.5$ & 4 & $<8$ \\
\hline SA07 & 128 & 1024 & 8 & - & - & - & $<0.5$ & 1 & $<2$ \\
\hline SA18 & 64 & 512 & 8 & 1024 & - & - & $<0.5$ & 8 & $<16$ \\
\hline$S A 23$ & 256 & 1024 & 4 & 512 & - & - & $<0.5$ & $<0.5$ & 1 \\
\hline$S A 36$ & 256 & 256 & 1 & 512 & - & - & 1 & 8 & 8 \\
\hline SA39 & 128 & 1024 & 8 & 1024 & - & - & $<0.5$ & 16 & $<32$ \\
\hline SA56 & 256 & 512 & 2 & 1024 & - & - & $<0.5$ & 4 & $<8$ \\
\hline SA64 & 128 & 512 & 4 & 1024 & - & - & 4 & 8 & 2 \\
\hline SA68 & 128 & 1024 & 8 & 1024 & - & - & $<0.5$ & $<0.5$ & 1 \\
\hline SA88 & 512 & 1024 & 2 & 1024 & - & - & $<0.5$ & 2 & $<4$ \\
\hline SA114 & 128 & 1024 & 8 & 1024 & - & - & $<0.5$ & $<0.5$ & 1 \\
\hline SA116 & 128 & 1024 & 8 & 1024 & - & - & $<0.5$ & $<0.5$ & 1 \\
\hline SA124 & 512 & 512 & 1 & 1024 & - & - & $<0.5$ & $<0.5$ & 1 \\
\hline SA126 & 128 & 512 & 4 & - & - & - & $<0.5$ & $<0.5$ & 1 \\
\hline SA127 & 256 & 512 & 2 & 1024 & - & - & $<0.5$ & $<0.5$ & 1 \\
\hline SA135 & 128 & 512 & 4 & 1024 & - & - & $<0.5$ & 1 & $<2$ \\
\hline SA139 & 256 & 1024 & 4 & - & - & - & $<0.5$ & $<0.5$ & 1 \\
\hline MSSA1 & 128 & 512 & 4 & 1024 & - & - & 2 & 16 & 8 \\
\hline$M R S A 3$ & 64 & 512 & 8 & 1024 & - & - & 2 & 16 & 8 \\
\hline MRSA4 & 64 & 128 & 2 & 256 & - & - & 1 & 16 & 16 \\
\hline MRSA6 & 64 & 128 & 2 & 1024 & - & - & 2 & 8 & 4 \\
\hline MRSA 8 & 128 & 512 & 4 & 1024 & - & - & 2 & 8 & 4 \\
\hline MRSA9 & 32 & 128 & 4 & 512 & - & - & 2 & 16 & 8 \\
\hline MRSA11 & 64 & 256 & 4 & 512 & - & - & 2 & 16 & 8 \\
\hline MRSA12 & 64 & 512 & 8 & 1024 & - & - & 2 & 4 & 2 \\
\hline
\end{tabular}

MBC/MIC; (-): > 1024; MIC value in bold: significant activity.

to at least one commonly used antibiotic [16-18, 26-30] (Tables S1 and S2). With regard to the diversity of plant secondary metabolites, their use as tools for antibacterial drug discovery is an attractive strategy. According to established criteria, MIC values in the range of $100-1000 \mu \mathrm{g} / \mathrm{mL}$ are indication that botanicals have antimicrobial activities [31]. Also, the antibacterial activity of plant extracts is considered significant if MIC values are below $100 \mu \mathrm{g} / \mathrm{mL}$, moderate if $100 \leq \mathrm{MICs} \leq 625 \mu \mathrm{g} / \mathrm{mL}$, and weak if MICs $>625 \mu \mathrm{g} / \mathrm{mL}$ [32]. Leaves extracts had MIC values below $100 \mu \mathrm{g} / \mathrm{mL}$ against $8 / 26$ tested $S$. aureus strains (Table 2 ). This clearly indicates that leaves extract of Syzygium jambos has good antistaphylococcal potential. Besides, MICs below $100 \mu \mathrm{g} / \mathrm{mL}$ were also obtained with this extract against two tested Gram-negative bacteria (Table 3), confirming the interesting antibacterial potential of the leaves extract contrary to the bark extract. These data are in accordance with previous antibacterial investigations of this plant. In effect, aqueous and acetone extract of the bark, leaves, and seeds of Syzygium jambos previously displayed antibacterial effects against sensitive strains of Staphylococcus aureus, Bacillus subtilis, Enterococcus gallinarum, Escherichia coli, Pseudomonas aeruginosa, Klebsiella pneumoniae, Proteus vulgaris, Enterococcus faecium, Salmonella typhi, and Vibrio cholera [14, 33]. Also, the methanol extract of leaves had antimicrobial activity against Alcaligenes faecalis, Bacillus subtilis, Staphylococcus aureus, and Aeromonas hydrophilia [34]. The present study focused on resistant phenotypes and therefore provides additional information on the good antibacterial activity of this plant and the ability of the leaves methanol extract to combat resistant phenotypes.

4.3. Antibiotic-Modulation Effects of Extracts. The ability of several botanicals and phytochemicals to modulate the antibiotic resistance has been reported [21, 23, 35]. Products able to potentiate the activity of antibiotics on more than $70 \%$ of bacteria have been suggested as potential efflux pumps inhibitors [36]. In this study, antibiotic-modulating activity of extracts at $\mathrm{MIC} / 2$ on more than $70 \%$ tested strains of S. aureus was obtained with the association leaves and bark extracts 
TABLE 3: MIC and MBC (in $\mu \mathrm{g} / \mathrm{mL}$ ) of extracts from Syzygium jambos and chloramphenicol against Gram-negative bacterial strains.

\begin{tabular}{|c|c|c|c|c|c|c|c|c|c|}
\hline \multirow{3}{*}{ Bacterial strains } & \multicolumn{9}{|c|}{ Tested sample, MIC, and MBC in $\mu \mathrm{g} / \mathrm{mL}$ and ratio $\mathrm{MBC} / \mathrm{MIC}$} \\
\hline & \multicolumn{3}{|c|}{ Leaves extract } & \multicolumn{3}{|c|}{ Bark extract } & \multicolumn{3}{|c|}{ Chloramphenicol } \\
\hline & MIC & MBC & $\mathrm{MBC} / \mathrm{MIC}$ & MIC & MBC & $\mathrm{MBC} / \mathrm{MIC}$ & MIC & $\mathrm{MBC}$ & $\mathrm{MBC} / \mathrm{MIC}$ \\
\hline \multicolumn{10}{|l|}{ Escherichia coli } \\
\hline ATTC8739 & 512 & 1024 & 2 & - & - & - & 8 & 64 & 8 \\
\hline ATCC10536 & 128 & 1024 & 8 & - & - & - & 4 & 16 & 4 \\
\hline AG100 & 512 & 1024 & 2 & 512 & 512 & 1 & 32 & 64 & 2 \\
\hline AG102 & 512 & 1024 & 2 & - & - & - & 32 & 256 & 8 \\
\hline AG100ATet & 256 & 512 & 2 & - & - & - & 4 & 32 & 8 \\
\hline MC4100 & 512 & 1024 & 2 & - & - & - & 128 & - & - \\
\hline W3110 & 512 & 1024 & 2 & - & - & - & 8 & 32 & 4 \\
\hline \multicolumn{10}{|c|}{ Enterobacter aerogenes } \\
\hline ATCC13048 & 256 & 1024 & 4 & 512 & - & - & 8 & 128 & 16 \\
\hline EA27 & 256 & 512 & 2 & 1024 & - & - & 128 & 256 & 2 \\
\hline EA289 & 512 & 1024 & 2 & 512 & 1024 & 2 & 4 & 64 & 16 \\
\hline EA294 & 64 & 512 & 8 & 512 & - & - & 2 & 256 & 128 \\
\hline EA 298 & 256 & 1024 & 4 & - & - & - & 8 & 128 & 16 \\
\hline \multicolumn{10}{|c|}{ Klebsiella pneumoniae } \\
\hline ATCC11296 & 256 & 512 & 2 & - & - & - & 8 & 256 & 32 \\
\hline K24 & 64 & - & - & - & - & - & 16 & 128 & 8 \\
\hline KP55 & 256 & 1024 & 4 & 512 & - & - & 64 & 128 & 2 \\
\hline KP63 & 128 & 1024 & 8 & - & - & - & 16 & 128 & 8 \\
\hline \multicolumn{10}{|c|}{ Providencia stuartii } \\
\hline PS2636 & 256 & 1024 & 4 & 1024 & - & - & 64 & 256 & 4 \\
\hline NEA16 & 128 & 1024 & 8 & 512 & - & - & 64 & 128 & 2 \\
\hline \multicolumn{10}{|c|}{ Enterobacter cloacae } \\
\hline ECCI69 & 512 & - & - & 512 & - & - & 128 & - & - \\
\hline \multicolumn{10}{|c|}{ Pseudomonas aeruginosa } \\
\hline PA01 & 512 & - & - & 512 & - & - & 128 & - & - \\
\hline PA124 & 512 & - & - & - & - & - & 32 & - & - \\
\hline
\end{tabular}

MBC/MIC; (-): >1024 $\mu \mathrm{g} / \mathrm{mL}$; MIC value in bold: significant activity.

and CHL (Tables 5 and 6). This was also the case with the combination of leaves extract with CHL, KAN, TET, and ERY (Table 7) as well as that of bark extract and CIP, TET, and ERY (Table 8) against Gram-negative bacteria. Consequently, the tested extracts and mostly the leaves extract can be explored more as potential efflux pump inhibitors [36]. To the best of our knowledge, the present study reports for the first time the ability of extracts from Syzygium jambos to modulate the activity of antibiotics towards resistant bacteria. It shows that this plant could be used in combination with some antibiotics to combat bacterial resistance to antibiotics. This is in accordance with previous studies on Cameroonian plants such as Brassica oleracea var. botrytis, Brassica oleracea var. italica, Capsicum frutescens var. fasciculatum, and Basilicum polystachyon which showed synergistic effects with a panel of antibiotics and MDR Gram-negative bacteria tested herein [23].

\section{Limitations}

Our study has limitations. It mainly reports the activity of crude plant extracts, and the identification of the active constituents of the plant would be necessary for better understanding of the reported effects. The toxicity of this plant also needs to be performed to evaluate its safety.

\section{Conclusion}

In the present study, the ability of Syzygium jambos and mostly the leaves methanol extract to fight resistant strains of Staphylococcus aureus as well as Gramnegative bacteria was demonstrated. It was also found that both leaves and bark extracts could be used as antibiotics resistance modulators, providing a new alternative 
TABLE 4: Preliminary antibiotic resistance modulatory activity of extracts at subinhibitory concentrations against S. aureus ST88 and P. aeruginosa PA124 strains.

\begin{tabular}{|c|c|c|c|c|c|c|c|c|c|}
\hline \multirow{2}{*}{$\begin{array}{l}\text { Plant } \\
\text { extracts and } \\
\text { bacterial strains }\end{array}$} & \multirow{2}{*}{$\begin{array}{l}\text { Extract } \\
\text { concentrations }\end{array}$} & \multicolumn{7}{|c|}{$\begin{array}{l}\text { Antibiotics, minimum inhibitory concentration }(\mu \mathrm{g} / \mathrm{mL}) \text {, and fold increase } \\
\text { (in brackets) }\end{array}$} & \multirow[b]{2}{*}{ KAN } \\
\hline & & $\mathrm{CHL}$ & TET & CIP & AMP & CEF & ERY & STR & \\
\hline \multirow[t]{2}{*}{ S. aureus $S A 88$} & 0 & 256 & - & 2 & - & - & 32 & 8 & 4 \\
\hline & $\mathrm{CMI} / 2$ & $64(4)$ & $32(>4)$ & $1(2)$ & $16(>16)$ & $8(>32)$ & $16(2)$ & $4(2)$ & $4(1)$ \\
\hline \multirow{4}{*}{ Leaves } & $\mathrm{CMI} / 4$ & $128(2)$ & $32(>4)$ & $1(2)$ & $256(>2)$ & $32(>8)$ & $64(0.5)$ & $4(2)$ & $4(1)$ \\
\hline & $\mathrm{CMI} / 8$ & $128(2)$ & - & $1(2)$ & $256(>2)$ & - & $64(0.5)$ & $4(2)$ & $4(1)$ \\
\hline & $\mathrm{CMI} / 16$ & $128(2)$ & - & $1(2)$ & - & - & $64(0.5)$ & $4(2)$ & $4(1)$ \\
\hline & $\mathrm{CMI} / 2$ & $32(8)$ & $64(>2)$ & $\leq 0.5(\geq 4)$ & - & - & $4(8)$ & $\leq 2(\geq 4)$ & $4(1)$ \\
\hline \multirow[t]{3}{*}{ Bark } & $\mathrm{CMI} / 4$ & $32(8)$ & $64(>2)$ & $\leq 0.5(\geq 4)$ & - & - & $4(8)$ & $\leq 2(\geq 4)$ & $4(1)$ \\
\hline & $\mathrm{CMI} / 8$ & $128(2)$ & - & $1(2)$ & - & - & $32(1)$ & $8(1)$ & $4(1)$ \\
\hline & $\mathrm{CMI} / 16$ & $128(2)$ & - & $2(1)$ & - & - & $32(1)$ & $16(0.5)$ & $4(1)$ \\
\hline \multirow[t]{2}{*}{ P. aeruginosa PA124 } & 0 & 32 & 16 & 16 & - & - & 32 & 64 & 64 \\
\hline & $\mathrm{CMI} / 2$ & $2(16)$ & $1(16)$ & $4(4)$ & - & - & $8(4)$ & $16(4)$ & $32(2)$ \\
\hline \multirow[t]{4}{*}{ Leaves } & $\mathrm{CMI} / 4$ & $4(8)$ & $1(\mathbf{1 6})$ & $4(2)$ & - & - & $32(1)$ & $32(2)$ & $32(2)$ \\
\hline & $\mathrm{CMI} / 8$ & $4(8)$ & $4(4)$ & $4(2)$ & - & - & $32(1)$ & $32(2)$ & $32(2)$ \\
\hline & CMI/16 & $4(8)$ & $4(4)$ & $16(1)$ & - & - & $32(1)$ & $32(2)$ & $32(2)$ \\
\hline & $\mathrm{CMI} / 2$ & $32(1)$ & $8(2)$ & $4(4)$ & - & - & $16(2)$ & $64(1)$ & $16(4)$ \\
\hline \multirow[t]{3}{*}{ Bark } & $\mathrm{CMI} / 4$ & $32(1)$ & $16(1)$ & $4(4)$ & - & - & $16(2)$ & $64(1)$ & $32(2)$ \\
\hline & $\mathrm{CMI} / 8$ & $32(1)$ & $16(1)$ & $4(4)$ & - & - & $16(1)$ & $64(1)$ & $64(1)$ \\
\hline & CMI/16 & $32(1)$ & $16(1)$ & $4(4)$ & - & - & $16(1)$ & $64(1)$ & $64(1)$ \\
\hline
\end{tabular}

AMP: ampicillin, CEF: cefepime, CIP: ciprofloxacin, Ery: erythromycin, KAN: kanamycin; STR: streptomycin, TET: tetracycline; (-): $>256 \mu \mathrm{g} / \mathrm{mL}$; fold increase in bold: significant effect.

in the fight against bacterial infections involving resistant phenotypes.

\section{Abbreviations}

ATCC: American Type Culture Collection

CEF: Cefepime

CFU: Colony forming unit

CHL: Chloramphenicol

CIP: Ciprofloxacin

DMSO: Dimethylsulfoxide

ERY: Erythromycin

INT: $\quad$-Iodonitrotetrazolium chloride

KAN: Kanamycin

MBC: Minimum bactericidal concentration

MDR: Multidrug-resistant

MHB: Mueller Hinton Broth

MIC: Minimum inhibitory concentration

MRSA: Methicillin-resistant Staphylococcus aureus

RA: $\quad$ Reference antibiotic

SA: $\quad$ Staphylococcus aureus

STR: Streptomycin

TET: Tetracycline.

\section{Conflicts of Interest}

The authors declare that they have no conflicts of interest.

\section{Authors' Contributions}

Brice E. N. Wamba, Paul Nayim, Igor K. Voukeng, Ornella J. T. Ngalani, and Joachim K. Dzotam carried out the study; Armelle T. Mbaveng and Victor Kuete designed the experiments. Armelle T. Mbaveng and Victor Kuete wrote the manuscript; Armelle T. Mbaveng and Victor Kuete supervised the work and provided the facilities for antibacterial assays; all authors read and approved the final manuscript. Brice E. N. Wamba and Paul Nayim contributed equally to the work.

\section{Acknowledgments}

The authors are thankful to the Cameroon National Herbarium for identification of plants. They also thank Dr. Jean P. Dzoyem (University of Dschang, Cameroon) for providing the MRSA strains of $S$. aureus. 


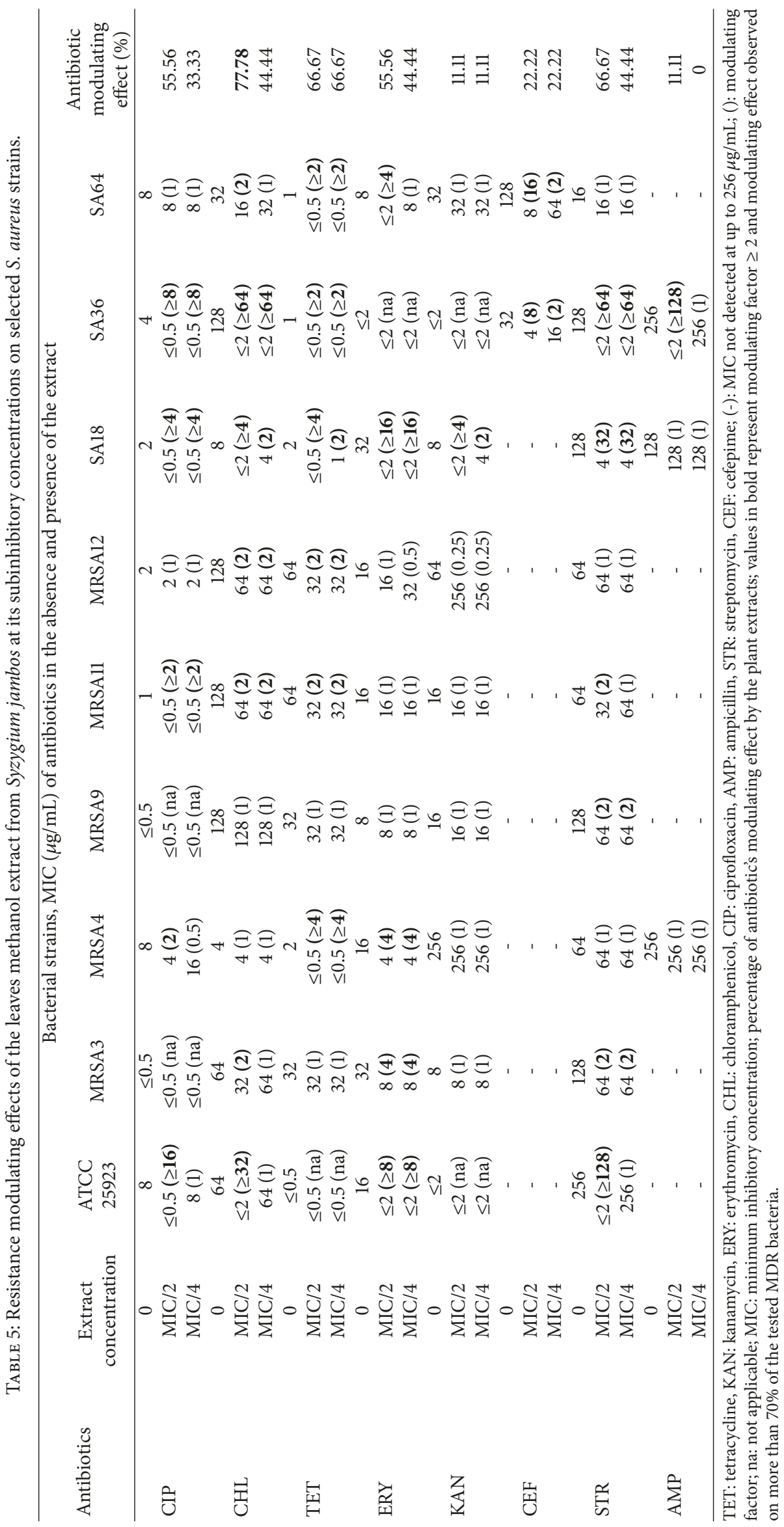




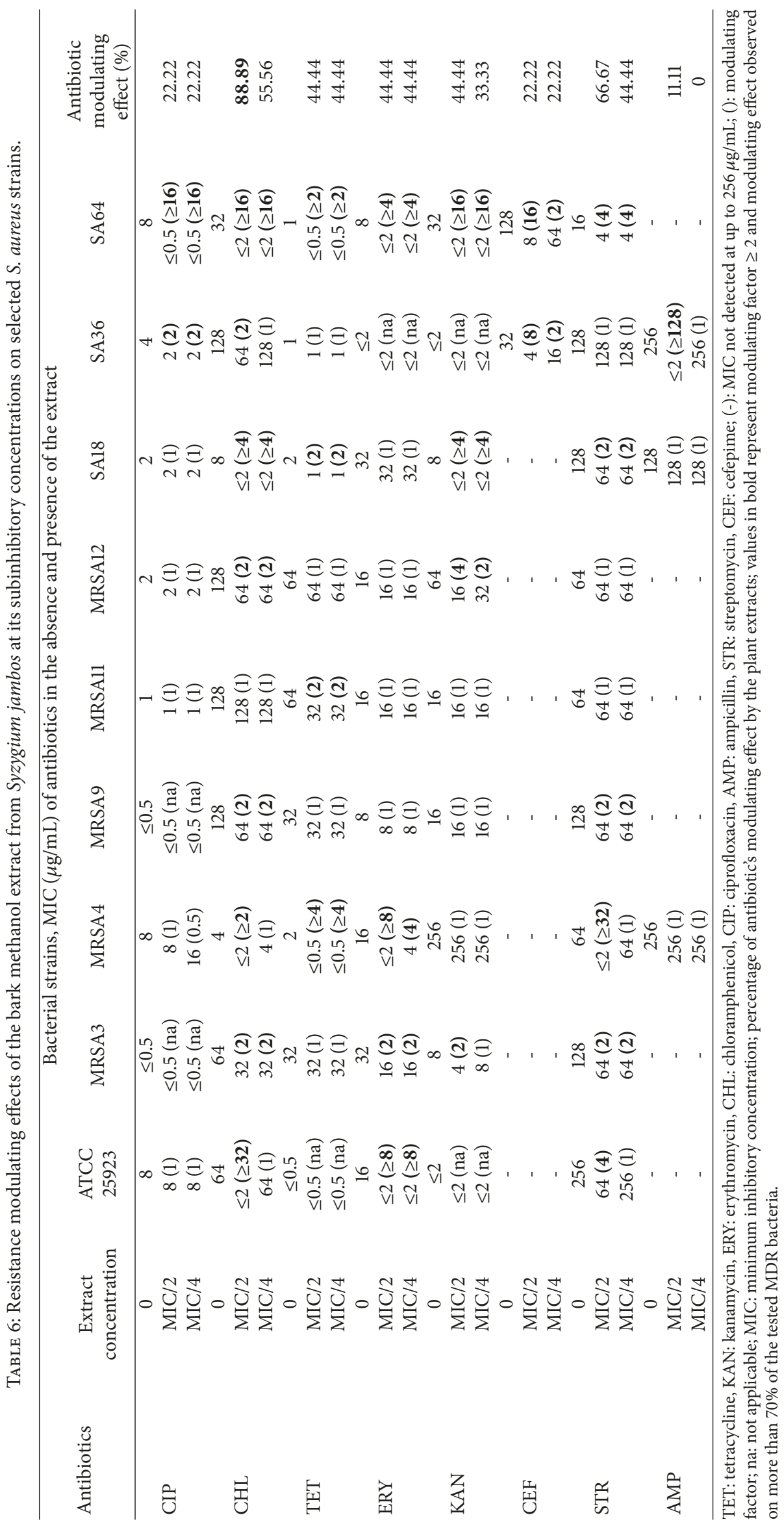




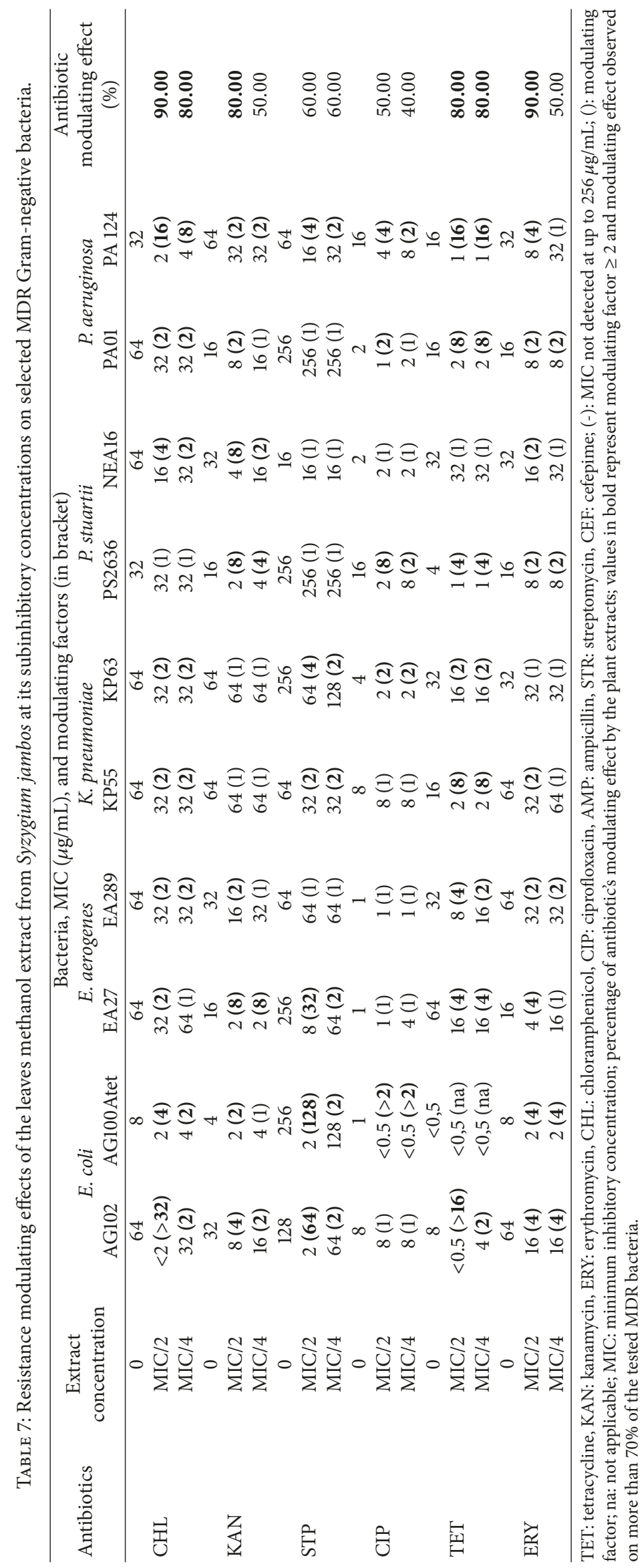




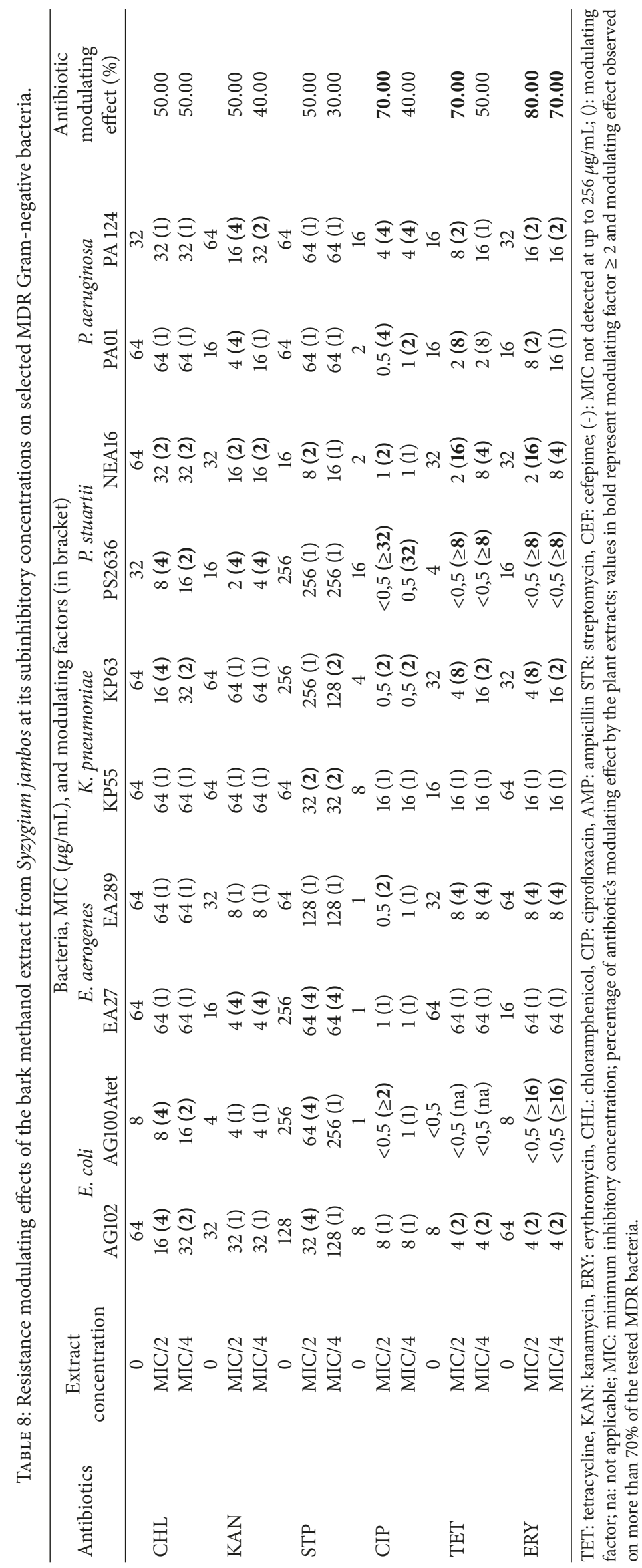




\section{Supplementary Materials}

Table S1: Staphylococcus aureus strains and features. Table S2: Gram-negative bacteria and features. (Supplementary Materials)

\section{References}

[1] C. Dye, "After 2015: infectious diseases in a new era of health and development," Philosophical Transactions of the Royal Society B: Biological Sciences, vol. 369, no. 1645, 2014.

[2] R. Lozano, M. Naghavi, and K. Foreman, "Global and regional mortality from 235 causes of death for 20 age groups in 1990 and 2010: a systematic analysis for the Global Burden of Disease Study 2010," The Lancet, vol. 380, no. 9859, pp. 2095-2128, 1990.

[3] M. M. Cowan, "Plant products as antimicrobial agents," Clinical Microbiology Reviews, vol. 12, no. 4, pp. 564-582, 1999.

[4] V. Kuete, "Medicinal plant research in Africa," in Pharmacology and Chemistry, V. Kuete, Ed., Elsevier, Oxford, UK, 2013.

[5] J. K. Dzotam, F. K. Touani, and V. Kuete, "Antibacterial and antibiotic-modifying activities of three food plants (Xanthosoma mafaffa Lam., Moringa oleifera (L.) Schott and Passiflora edulis Sims) against multidrug-resistant (MDR) Gram-negative bacteria," BMC Complementary and Alternative Medicine, vol. 16, no. 1, article 9, 2016.

[6] D. E. Djeussi, J. A. K. Noumedem, B. T. Ngadjui, and V. Kuete, "Antibacterial and antibiotic-modulation activity of six Cameroonian medicinal plants against Gram-negative multidrug resistant phenotypes," BMC Complementary and Alternative Medicine, vol. 16, no. 1, article 124, 2016.

[7] J. A. Seukep, L. P. Sandjo, B. T. Ngadjui, and V. Kuete, "Antibacterial and antibiotic-resistance modifying activity of the extracts and compounds from Nauclea pobeguinii against Gram-negative multi-drug resistant phenotypes," BMC Complementary and Alternative Medicine, vol. 16, no. 1, article 193, 2016.

[8] I. K. Voukeng, V. P. Beng, and V. Kuete, "Antibacterial activity of six medicinal Cameroonian plants against Gram-positive and Gram-negative multidrug resistant phenotypes," BMC Complementary and Alternative Medicine, vol. 16, no. 1, article 388, 2016.

[9] C. F. Tchinda, I. K. Voukeng, V. P. Beng, and V. Kuete, "Antibacterial activities of the methanol extracts of Albizia adianthifolia, Alchornea laxiflora, Laportea ovalifolia and three other Cameroonian plants against multi-drug resistant Gramnegative bacteria," Saudi Journal of Biological Sciences, vol. 24, no. 4, pp. 950-955, 2017.

[10] J. K. Dzotam and V. Kuete, "Antibacterial and antibioticmodifying activity of methanol extracts from six Cameroonian food plants against multidrug-resistant enteric bacteria," BioMed Research International, vol. 2017, Article ID 1583510, 19 pages, 2017.

[11] A. G. Fankam, J.-R. Kuiate, and V. Kuete, "Antibacterial and antibiotic resistance modulatory activities of leaves and bark extracts of Recinodindron heudelotii (Euphorbiaceae) against multidrug-resistant Gram-negative bacteria," BMC Complementary and Alternative Medicine, vol. 17, no. 1, article 168, 2017.

[12] I. K. Voukeng, V. P. Beng, and V. Kuete, "Multidrug resistant bacteria are sensitive to Euphorbia prostrata and six others Cameroonian medicinal plants extracts," BMC Research Notes, vol. 10, no. 1, article 321, 2017.
[13] E. J. Adjanohoun, Contribution aux études ethnobotaniques et floristiques en République Populaire du Bénin. Médécine traditionnelle et pharmacopée, Agence de Coopération Culturelle et Technique, Paris, France, 1989.

[14] S. Murugan, D. P. Uma, P. N. Kannika, and K. R. Mani, "Antimicrobial activity of Syzygium jambos against selected human pathogens," International Journal of Pharmacy and Pharmaceutical Sciences, vol. 3, pp. 44-47, 2011.

[15] L. Hoareau and J. E. DaSilva, "Medicinal plants: a re-emerging health aid," Electronic Journal of Biotechnology, vol. 2, pp. 56-70, 1999.

[16] A. Paudel, H. Hamamoto, Y. Kobayashi, S. Yokoshima, T. Fukuyama, and K. Sekimizu, "Identification of novel deoxyribofuranosyl indole antimicrobial agents," The Journal of Antibiotics, vol. 65, no. 2, pp. 53-57, 2012.

[17] J. P. Dzoyem, H. Hamamoto, B. Ngameni, B. T. Ngadjui, and K. Sekimizu, "Antimicrobial action mechanism of flavonoids from dorstenia species," Drug Discoveries \& Therapeutics, vol. 7, no. 2, pp. 66-72, 2013.

[18] T. J. O. Ngalani, Influence de la multi-résistance des bactéries entériques aux antibiotiques sur l'état immunologique des patients séropositifs au VIH venus en consultation à l'hôpital Adlucem Banka de Bafang, Department of Biochemistry, University of Dschang, Dschang, Cameroon, 2015.

[19] J. Harbone, Phytochemical Methods: A Guide to Modern Techniques of Plant Analysis, Chapman \& Hall, London, UK, 1973.

[20] J. N. Eloff, "A sensitive and quick microplate method to determine the minimal inhibitory concentration of plant extracts for bacteria," Planta Medica, vol. 64, no. 8, pp. 711-713, 1998.

[21] D. E. Djeussi, J. A. K. Noumedem, J. A. Seukep et al., "Antibacterial activities of selected edible plants extracts against multidrug-resistant Gram-negative bacteria," BMC Complementary and Alternative Medicine, vol. 13, no. 1, article 164, 2013.

[22] F. K. Touani, A. J. Seukep, D. E. Djeussi, A. G. Fankam, J. A. K. Noumedem, and V. Kuete, "Antibiotic-potentiation activities of four Cameroonian dietary plants against multidrug-resistant Gram-negative bacteria expressing efflux pumps," BMC Complementary and Alternative Medicine, vol. 14, article 258, 2014.

[23] J. Kovač, N. Gavari, F. Bucar, and S. Smole Možina, "Antimicrobial and resistance modulatory activity of Alpinia katsumadai seed phenolic extract, essential oil and post-distillation extract," Food Technology and Biotechnology, vol. 52, pp. 248-254, 2014.

[24] J. Bruneton, Pharmacognosie: Phytochimie, Plantes Medicinales, Tec \& Doc, Paris, France, 1999.

[25] J.-R. Kuiate, S. Mouokeu, H. K. Wabo, and P. Tane, "Antidermatophytic triterpenoids from Syzygium jambos (L.) Alston (Myrtaceae)," Phytotherapy Research, vol. 21, no. 2, pp. 149-152, 2007.

[26] J. Chevalier, J.-M. Pages, A. Eyraud, and M. Mallea, "Membrane permeability modifications are involved in antibiotic resistance in Klebsiella pneumoniae," Biochemical and Biophysical Research Communications, vol. 274, no. 2, pp. 496-499, 2000.

[27] E. Pradel and J.-M. Pages, "The AcrAB-TolC efflux pump contributes to multidrug resistance in the nosocomial pathogen Enterobacter aerogenes," Antimicrobial Agents and Chemotherapy, vol. 46, no. 8, pp. 2640-2643, 2002.

[28] A. Davin-Regli, J.-M. Bolla, C. E. James et al., "Membrane permeability and regulation of drug "influx and efflux" in enterobacterial pathogens," Current Drug Targets, vol. 9, no. 9, pp. 750-759, 2008. 
[29] V. Kuete, B. Ngameni, J. G. Tangmouo et al., "Efflux pumps are involved in the defense of gram-negative bacteria against the natural products isobavachalcone and diospyrone," Antimicrobial Agents and Chemotherapy, vol. 54, no. 5, pp. 1749-1752, 2010.

[30] V. Kuete, S. Alibert-Franco, K. O. Eyong et al., "Antibacterial activity of some natural products against bacteria expressing a multidrug-resistant phenotype," International Journal of Antimicrobial Agents, vol. 37, no. 2, pp. 156-161, 2011.

[31] M. Simões, R. N. Bennett, and E. A. S. Rosa, "Understanding antimicrobial activities of phytochemicals against multidrug resistant bacteria and biofilms," Natural Product Reports, vol. 26, no. 6, pp. 746-757, 2009.

[32] V. Kuete, "Potential of Cameroonian plants and derived products against microbial infections: A review," Planta Medica, vol. 76, no. 14, pp. 1479-1491, 2010.

[33] C. D. Djipa, M. Delmée, and J. Quetin-Leclercq, "Antimicrobial activity of bark extracts of Syzygium jambos (L.) Alston (Myrtaceae)," Journal of Ethnopharmacology, vol. 71, no. 1-2, pp. 307313, 2000.

[34] S. Mohanty and I. E. Cock, "Bioactivity of Syzygium jambos methanolic extracts: antibacterial activity and toxicity," Pharmacognosy Research, vol. 2, no. 1, pp. 4-9, 2010.

[35] S. B. Tankeo, P. Tane, and V. Kuete, "In vitro antibacterial and antibiotic-potentiation activities of the methanol extracts from Beilschmiedia acuta, Clausena anisata, Newbouldia laevis and Polyscias fulva against multidrug-resistant Gram-negative bacteria," BMC Complementary and Alternative Medicine, vol. 15, no. 1, article 412, 2015.

[36] L. C. Braga, A. A. M. Leite, K. G. S. Xavier et al., "Synergic interaction between pomegranate extract and antibiotics against Staphylococcus aureus," Canadian Journal of Microbiology, vol. 51, no. 7, pp. 541-547, 2005. 


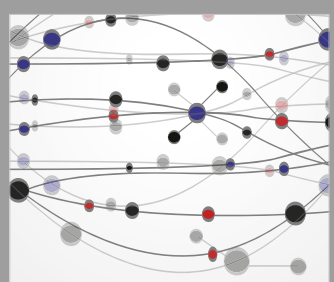

The Scientific World Journal
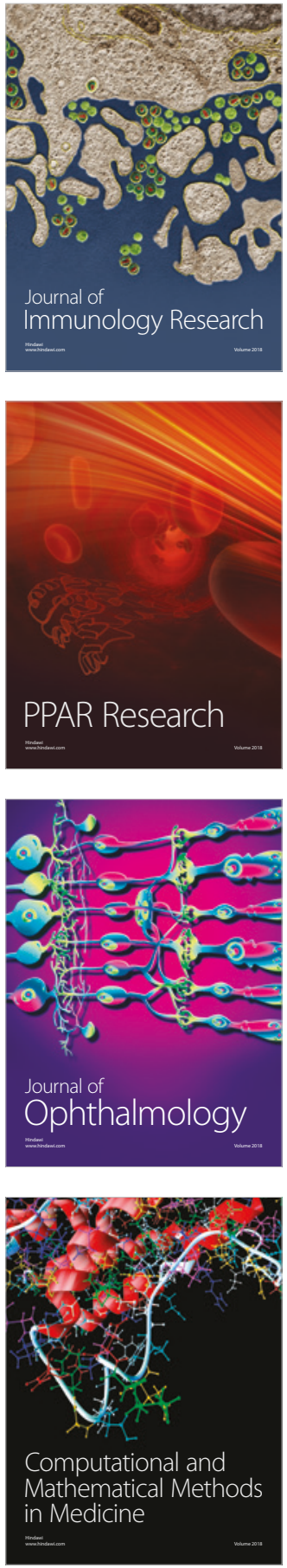

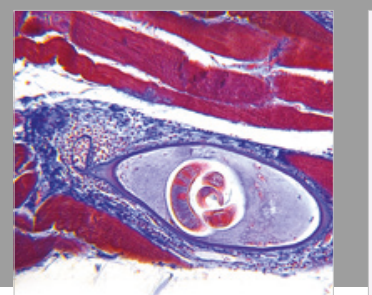

Gastroenterology Research and Practice

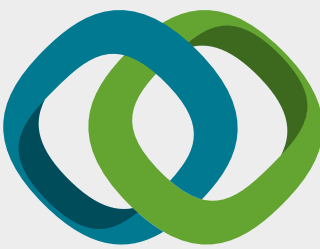

\section{Hindawi}

Submit your manuscripts at

www.hindawi.com
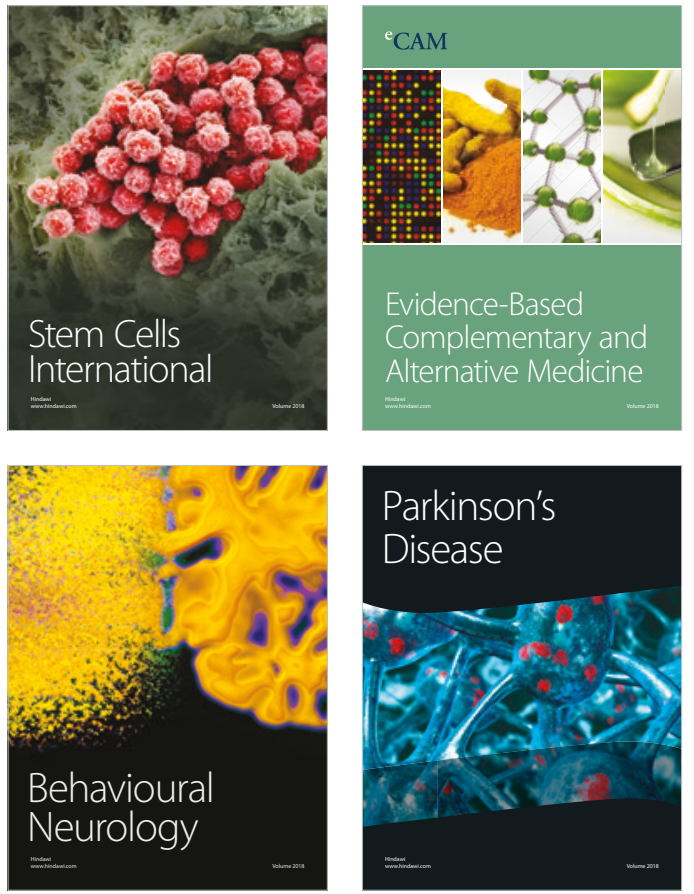

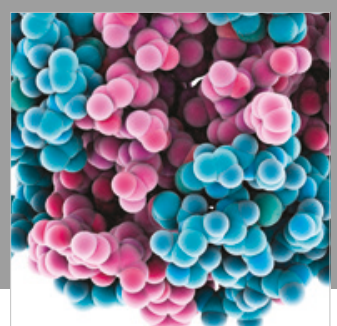

ournal of

Diabetes Research

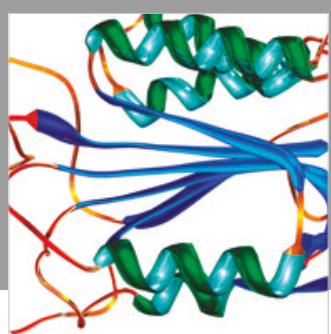

Disease Markers
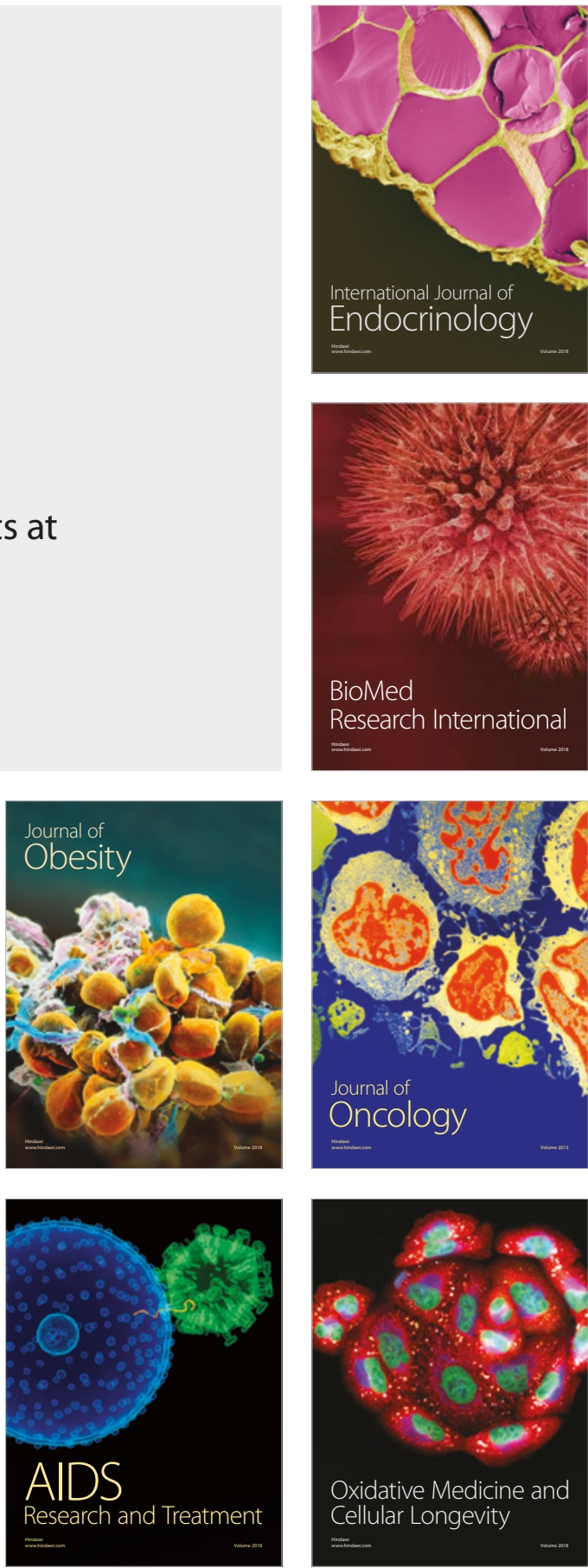